Extended Abstract

\title{
Social Classes and Digital Activism
}

\author{
Dr. Bianca MITU1,* \\ ${ }^{1}$ University of Huddersfield / Queensgate, Huddersfield, UK \\ ${ }^{2}$ Postdoctoral Fellow Romanian Academy / 125, Calea Victoriei, sector 1, RO - 010071, Bucharest, \\ ROMANIA
}

E-Mails: bianca.mitu82@gmail.com

* Author to whom correspondence should be addressed:

Bianca Mitu

3 Bank Buildings, Huddersfield, UK, HD9 4BA

Tel.: 07440666429

Accepted: 28.02.2015

\section{Introduction (M_Heading1)}

Based on Marx's pyramid of capitalist system, this article outlines some of the contemporary approaches of the digital activism and elaborates a critique of these approaches. Marx and Engels (1970) state that "the ideas of the ruling class are in every epoch the ruling ideas, i.e. the class which is the ruling material force of society, is at the same time its ruling intellectual force. The class which has the means of material production at its disposal, has control at the same time over the means of mental production, so that thereby, generally speaking, the ideas of those who lack the means of mental production are subject to it. The ruling ideas are nothing more than the ideal expression of the dominant material relationships, the dominant material relationships grasped as ideas" (1970: 58). If we apply this to the ongoing debates about the development of the internet and internet use, we are facing the situation of the ruling classes (those who have access to the Internet) that decide over the working classes (those many who do not have access to the Internet and therefore do not have the means to impose their ideas/ willing). According to the statistics (http://www.internetworldstats.com/stats.htm, 2014) right now the people from richer countries are the ones that are able to participate in digital activism, as Mary Joyce also states: "people in richer 
countries are usually more able to participate in digital activism because of the cost and quality of Internet connections available to them" (2010: 3). The present research aims to answer to the following questions: Can we talk about online social classes today? What social classes engage in the online protests? The study provides a critique analysis of the digital activism and, starting from Marx's theory of social class, introduces the idea of online social class and analyses the characteristics of each online social class on the basis of their participation to online protests. According to Denning (2001: 241), activism is "the use of the Internet in support of an agenda or cause". This includes online actions like setting up websites, surfing the web for information, posting materials on a website, transmitting electronic publications and letters through email, and using the Internet to discuss issues, form coalitions, and coordinate activities. This research considers digital activism as the use of the Internet or any other Internet- based application in supporting of a political or social cause. Thereby, the activism through Internet include the searching for information, expressing of own opinions on certain social problems, and the use of applications based on Internet to mobilize people to participate in a "real", physical manifestation. The success an online protest is based on five modes of Internet use: a) collection; b) publication; c) dialogue; d) coordination of action, and e) direct lobbying of decision makers (Denning, 2001: 243). The online social classes are analyzed according to people's use of specific websites and to their engagement in online protests. For this purpose we analysed people's online engagement on Facebook on four different protest occasions: the Egyptian protests that took place in Tahrir square in Cairo, the protests that took place in Taksim square in Istanbul, the Indignants movement that took place in different countries, and the Indignants movement that led to Occupy Wall Street movement.

\section{Methods (M_Heading1)}

Employing a large survey and a qualitative study of a purposively sampled community of citizens and internet users, this project wishes to explore how do social classes' characteristics translate into specific uses of the web and of engaging with online protests. Furthermore, I aim to provide a comprehensive content analysis of people's engagement in 4 protests on Facebook juxtaposed with a user experience study.

\section{Acknowledgments}

This paper is supported by the Sectorial Operational Programme Human Resources Development (SOP HRD), financed from the European Social Fund and by the Romanian Government under the contract number SOPHRD/159/1.5/S/136077. 


\section{References and Notes}

Albrechtslund, A. (2008). Online Social Networking as Participatory Surveillance. 13(3). pp. n.d. Retrieved from http://firstmonday.org/ojs/index.php/fm/article/viewArticle/2142/1949.

Atton, C. (2002). Alternative media. Thousand Oaks CA: Sage Publications.

Barzilai-Nahon, K. (2008). "Toward a Theory of Network Gatekeeping: A Framework for Exploring Information Control". Journal of the American Society for Information Science and Technology 59 (9): 1493-512.

Bohman,J. (2004). "Expanding dialogue: The Internet, the public sphere and prospects for transnational democracy”. The Sociological Review. 52. 131-155.

Bruns, \& Burgess (2012). Notes Towards the Scientific Study of Public Communication on Twitter. In Tokar, A., Beurskens, M., Keuneke, S., Mahrt, M., Peters, I., Puschmann, C., van Treeck, T., \& Weller, K. (Eds.). (2012). Science and the Internet (pp. 159-169). Düsseldorf: Düsseldorf University Press.

Brodock, K. (2010). Economic and Social Factors: the Digital (activism) Divide. In Joyce, M. (ed). Digital Activism Decoded: the New Mechanics of Change. New York: International Debate Education Association, pp. 71-85.

Bennett, W., Wells, C., \& Freelon, D. (2011). Communicating Civic Engagement: Contrasting Models of Citizenship in the Youth Web Sphere. Journal of Communication 61, pp. 835-856.

Boyd, D. \& Ellison N. (2007). Social network sites: Definition, history, and scholarship. In Journal of Computer-Mediated Communication, 13(1), article 11.

Dahlgren, P. (2005). "The Internet, Public Spheres, and Political Communication: Dispersion and Deliberation". Political Communication. 22. 147-162.

Dallas Lawrence (7/15/2010). How Political Activism Are Making The Most Of Social Media. Forbes. Retrieved from http://www.forbes.com/2010/07/15/social-media-social-activism-facebook-twitterleadership-citizenship-burson.html

Denning, D. (2000). Activism, hacktivism, and cyberterrorism: The Internet as a tool for influencing foreign policy. The Computer Security Journal, XVI (Summer), pp. 15-35.

Denning, D. (2001). Activism, Hacktivism, and Cyberterrorism: the internet as a tool for influencing foreign policy. In Arquilla, J., \& Ronfeldt, D. RAND, pp. 239, 288.

Edwards, F., Howard, P., \& Joyce, M. (2013). Digital Activism \& Non - Violent Conflict. Retrieved from: digital-activism.org/download/1270

Ferdinand, P. (ed.) (2000). The Internet, Democracy and Democratization. London: Frank Cass Publishers. 
Fisher, E. (2015) Class struggles in the digital frontier: audience labour theory and social media users. Information, Communication \& Society. DOI: 10.1080/1369118X.2015.1018300

Fuchs, C. (2006). The Self-Organization of Cyberprotest. K. Morgan, Konrad, C. Brebbia \& J. Spector (Eds.), The Internet Society II. Advances in Education, Comerce \& Governance. Southampton/Boston: WIT Press. pp. 275-295.

Carlos and J. Michael Spector (2006). The Internet Society II: Advances in Education, Commerce \& Governance. Southampton, Boston, WIT Press: 275-295.

Gibson, W. (1984). Neuromancer, New York: Ace Science Fiction Books.

Hargittai, E., \& Hinnant, A. (2008). Digital inequality: Differences in young adults' use of the Internet. In Communication Research, 35(5), 602-621. doi:10.1111/j.1460-2466.2011.01588.x

Internet World Stats (2014). Facebook. Retrieved from: www.internetworldstats.com/facebook.htm

Jiang, B. \& Ormeling, F. (1999). Mapping cyberspace: Visualising, anañysing and exploring virtual worlds. London: Center for Advanced Spatial Anañysis.

Joyce, M. (2010). Digital Activism Decoded: the New Mechanics of Change, New York: International Debate Education Association.

Marx, K. \& Engels, F. (1970). The German Ideology. London: Lawrence \& Wishart.

Meghan, P. (July, 2014). A Brief History of Online Activism. Retrieved from: http://mashable.com/2011/08/15/online-activism/

Papacharissi, Z. \& Gibson, P. L. (2011). Fifteen Minutes of Privacy: Privacy, Sociality and Publicity on Social Network Sites. In S. Trepte and L. Reinecke (eds.), Privacy Online: Perspectives on Privacy and Self-Disclosure in the Social Web. London, New York: Springer.

Poster, M. (1997), "Cyberdemocracy: The Internet and the Public Sphere" in Holmes, D. (ed.), Cyberdemocracy, London, Sage Publications.(C) 2015 by the authors; licensee MDPI and ISIS. This abstract is distributed under the terms and conditions of the Creative Commons Attribution license. 